\title{
Pemikiran Moral dan Faktor-Faktor Pribadi Mahasiwa terhadap Perilaku Moral
}

\author{
TRI WIDYASTUTI, MEILIYAH ARIANI
}

\author{
Pascasarjana, Jurusan Agronomi, Universitas Jember, Jember, Indonesia \\ Email Korespondensi: triewidhiastuti@yahoo.com
}

\begin{abstract}
Abstrak
Penelitian ini bertujuan untuk menguji pengaruh pemikiran moral dan faktor-faktor pribadi mahasiswa terhadap perilaku moral mahasiswa akuntansi dalam empat komponen dasar yang mendasari setiap tindakan moral atau perilaku moral seseorang individu dalam berperilaku secara moral. Selain itu juga untuk menguji pengaruh variable demografis mahasiswa akuntansi seperti jenis kelamin, IPK dan umur terhadap perilaku moral mereka. Pemilihan sampel dilakukan dengan menggunakan metode purposive sampling. Data penelitian ini dikumpulkan dari mahasiswa akuntansi Universitas Pancasila Jakarta tahun ajaran 2011/2012. Jumlah sampel yang digunakan adalah mahasiswa akuntansi semester 5 sampai 8 yang berjumlah 150 mahasiswa. Teknik Analisis yang digunakan adalah regresi berganda dalam SPSS ver.19. Dari hasil penelitian menunjukan pemikiran moral dan faktor-faktor pribadi mahasiswa berpengaruh positif dan signifikan terhadap perilaku moral mahasiswa akuntansi secara simultan. Sedangkan faktor - faktor pribadi mahasiswa yang diukur dengan tingkat idealisme, tingkat relativisme secara partial mempunyai pengaruh positif dan signifikan terhadap perilaku moral mahasiswa. Dan faktor - faktor pribadi mahasiswa yang lain yang diukur dengan locus of control, jenis kelamin, IPK dan umur mempunyai pengaruh yang tidak signifikan terhadap perilaku moral secara partial.
\end{abstract}

Kata Kunci: Pemikiran moral \& faktor-faktor pribadi mahasiswa, perilaku moral

\section{Moral Thinking and Student Personal Factors on Moral Behavior}

\begin{abstract}
This study is aimed to examine the effect of moral reasoning and the student's personal factors towards moral behaviour of accounting students in the four basic components to behave underlying of any moral actions or moral behaviour of an individual. In addition to that, it is also to examine the effect of accounting student demographic variables such as sex, Grade Point Average (GPA), and age towards their moral behaviour. The sample selected is done by using a purposive sampling method. Research data was collected from Accounting students of Pancasila University, Jakarta within academic enrollment year 2011/2012. The number of samples used are Accounting students of the 5th to 8th semester totaling 150 students. The analysis technique used is a multiple regression in SPPS ver.19. The results of the study shows moral reasoning and student's personal factors influence positively and significantly towards the moral behaviour of accounting students simultaneously. Meanwhile, student's personal factors which measured in the level of idealism, level of relativism in partial has positive and significant impact on student's moral behaviour. And, others student's personal factors are measured with locus of control, sex, GPA, and age has no significant influence towards moral behaviour partially.
\end{abstract}

Keywords: Moral reasoning and personal factors of students, moral behavior 


\section{PENDAHULUAN}

Perkembangan profesi akuntan di Indonesia yang merupakan salah satu proses kunci di era globalisasi menjadi sangat penting dalam kaitannya dengan percepatan bisnis yang semakin global. Peran akuntan semakin meningkat dalam usaha mewujudkan good corporate governance. Untuk itu, diperlukan persiapan yang berkitan dengan profesionalisme profesi akuntan. Pendidikan moral dan etika telah diakui mempunyai peranan penting dalam perkembangan profesi di bidang akuntansi. Hal ini menunjukkan urgensi dari perilaku moral, terutama bagi perkembangan ilmu akuntansi dalam kaitannya dengan aspek perilaku yang terlibat didalamnya. Aspek perilaku dalam akuntansi telah dibahas secara spesifik dalam mata kuliah Akuntansi Keperilakuan. Akuntansi Keperilakuan membahasa tentang perilaku manusia dan hubungannya dengan data akuntansi dan keputusan bisnis, dan sebaliknya bagaimana informasi akuntansi mempengaruhi keputusan bisnis dan perilaku manusia.

Terbongkarnya kasus - kasus khususnya ilmu akuntansi, yaitu dengan terbongkarnya kasus Enron Corp. (2001) dan kasus di dalam negeri yaitu PT Kimia Farma Tbk (2001), PT Bank Capital Indonesia (2010) Tbk dan kasus-kasus perusahaan besar lainnya yang terlibat dalam praktik manajemen laba memberikan kesadaran tentang betapa pentingnya peran dunia pendidikan dalam menciptakan sumber daya manusia yang cerdas dan bermoral. Prinsip-prinsip good governance juga menyatakan bahwa sikap independen, transparans, adil, dan akuntabel harus dimiliki oleh semua pengelola organisasi, baik swasta maupun pemerintah. Begitu pula halnya perilaku moral para akuntan profesional penting untuk status dan kredibilitasnya terhadap etika profesi akuntansi.

\section{KAJIAN LITERATUR}

Rest (1986) dalam (Chan dan Leung), 2006) telah mengembangkan sebuah model dari komponen komponen hipotesis yang mendasari setiap tindakan moral. Rest menggagas suatu empat model komponen untuk meneliti pengaruh proses pemikiran moral dan tingkah laku moral individu. Dia mengatakan bahwa untuk bertingkah laku secara moral, seorang individu melakukan empat proses psikologi, yaitu : Sensitivitas
Moral (Moral Sensitivity), Pertimbangan Moral (Moral Judgment), Motivasi Moral (Moral Motivation), dan Karakter Moral (Moral Character).

Penekanan pentingnya etika profesi khususnya bagi profesional di bidang akuntansi semakin menjadi perhatian penting terhadap penelitian etika dilakukan, mengingat beberapa kasus dibidang keuangan yang terjadi tak lepas dari akibat diabaikannya masalah etika profesi (Santoso, 2002) yang menimbulkan citra negatif terhadap profesi akuntan publik. Hal ini tentu saja akan merusak citra profesi akuntan di masyarakat yang pada akhirnya menurunkan kepercayaan masyarakat terhadap profesi akuntan.

Penelitian pengembangan etika akuntan profesional seharusnya dimulai dengan penelitian mahasiswa akuntansi dibangku kuliah, dimana mahasiswa akuntansi ditanamkan perilaku moral dan nilainilai profesional akuntan (Jeffrey, 1993). Menurut Ponemon dan Glazer (1990) bahwa sosialisasi etika profesi akuntan pada kenyataannya berawal dari masa kuliah, dimana mahasiswa akuntansi sebagai calon akuntan profesional di masa datang.

Berdasarkan uraian hasil penelitian pengaruh pemikiran moral dan faktor-faktor pribadi terhadap perilaku moral mahasiswa dalam model empat komponen Rest (Chan dan Leung, 2006) dan penelitian yang telah dilakukan oleh Ponemon dan Glazer (1990) dan Jeffrey dan Leung (2006) serta penelitian yang pernah dilakukan di dalam negeri yaitu Marwanto (2007) terhadap mahasiswa akuntansi Politeknik (D3) Negeri Samarinda, sebagai dasar penelitian dengan menggunakan semua komponen perilaku moral dari model Rest.

Penekanan penelitian ini pada pemikiran moral dan faktor-faktor pribadi yang diukur dengan tingkat idealisme, tingkat relativisme, locus of control, jenis kelamin, indeks prestasi kumulatif dan umur yang mempengaruhi empat model komponen Rest sebagai bagian dari aspek individual yang mempengaruhi perilaku moral mahasiswa akuntansi di dasarkan pada teori Rest (1983) bahwa seorang individu berperilaku secara moral minimal melakukan empat tahap psikologi dasar. Penelitian ini merupakan studi eksperimen pada mahasiswa akuntansi fakultas ekonomi Universitas Pancasila Jakarta. 


\section{METODE}

Model dan desain penelitian ini adalah untuk memperoleh data tentang variable-variabel yang mempengaruhi pemikiran moral dan faktor-faktor pribadi mahasiswa. Jenis penelitian yang digunakan dalam penelitian ini adalah penelitian eksperimen yaitu penelitian yang menggunakan treatment berupa skenario dalam kuesioner. Sumber data yang dipakai dalam penelitian ini adalah data subyek, yaitu data yang berupa opini, sikap, pengalaman atau karakteristik dari seseorang atau kelompok orang yang menjadi subyek penelitian (responden). Sedangkan jenis data dalam penelitian ini adalah data primer, yaitu data yang diperoleh langsung dari sumber aslinya.

Populasi dalam penelitian ini adalah mahasiswa akuntansi pada Universitas Pancasila pada tahun ajaran 2011/2012 berjumlah 339 mahasiswa. Rencana kuesioner yang akan dibagikan kepada mahasiswa akuntansi semester 5 sampai 8 yang berjumlah 150 mahasiswa sebagai sampel responden dari jumlah mahasiswa akuntansi pada tahun ajaran 2011/2012.

Teknik pengambilan sampel dilakukan secara purposive sampling berdasarkan pertimbangan (judgement) yaitu metode pemilihan sampel dengan tujuan atau target tertentu dengan pertimbanganpertimbangan tertentu (Indriantoro dan Supomo, 2009). Pertimbangan pemilihan mahasiswa akuntansi semester 5 sampai 8 Universitas Pancasila karena mahasiswa - mahasiswa akuntansi mendapat mata kuliah Etika Bisnis dan Profesi Akuntan. Selain itu, mahasiswa yang duduk di semester 5 sampai 8 telah menempuh semua mata kuliah akuntansi, mata kuliah Analisis Standar Profesional Akuntan Publik dan Pratikum Audit. Sehingga seluruh mahasiswa SI akuntansi semester 5 sampai 8 diharapkan mampu menjadi responden dalam penelitian ini.

Teknik pengambilan sampel dalam penelitian ini dapat dibuat kriteria sebagai berikut. Pertama, mahasiswa semester $\mathrm{V}$ yang telah menempuh mata kuliah Pratikum Audit 1 dan mata kuliah Etika Bisnis \& Profesi Akuntan. Kedua, mahasiswa semester VI yang telah menempu mata kuliah Pratikum Audit II dan Analisis Standar Profesional Akuntan Publik. Ketiga, mahasiswa semester VII yang sudah menempuh semua mata kuliah akuntansi. Keempat, mahasiswa semester VIII yang sudah menempu semua mata kuliah akuntansi dan sedang dalam penyusunan skripsi.

Data Penelitian yang akan dianalisis menggunakan alat analisis dengan menggunakan SPSS yang terdiri dari : statistik deskriptif, uji kualitas data yaitu uji reliabilitas dan uji validitas, uji asumsi klasik, dan uji hipotesis dengan persamaan regresi berganda (multiple regression) yaitu sebagai berikut :

$Y=a+\beta_{1} \cdot X_{1}+\beta_{2} \cdot X_{2}+e$

Keterangan:

$$
\begin{array}{ll}
\mathrm{Y} & =\text { Perilaku Moral Mahasiswa } \\
\mathrm{a} & =\text { Konstanta } \\
\beta & =\text { Slope atau Koefisien Regresi } \\
\mathrm{X}_{1} & =\text { Pemikiran Moral } \\
\mathrm{X}_{2} & =\text { Faktor-Faktor Pribadi Mahasiswa } \\
\mathrm{e} & =\text { Error }
\end{array}
$$

Pemikiran Moral dan Faktor - Faktor Pribadi Mahasiswa Berpengaruh Signifikan Terhadap Perilaku Moral Mahasiswa Secara Parsial

Rest (1986) dalam (Chang dan Leung, 2006) menyatakan bahwa empat komponen Rest berhubungan dengan pemikiran moral. Arnold dan ponemon (1991) telah meneliti hubungan antara pemikiran moral auditor dengan persepsi whistleblowing, yang mengatakan bahwa auditor intern dengan tingkat yang relatif lebih tinggi atas pemikiran moral dapat mengidentifikasikan dan mengetahui perilaku yang kurang pantas.

Penelitian sebelumnya mengenai faktor - faktor pribadi mahasiswa yang diukur dengan dengan faktor idealisme dan reletivisme (Ellas, 2003; Forsyth, 1980; Schlenker dan Forsyth, 1977) menyatakan bahwa idealisme mengacu pada tingkat seorang individu percaya bahwa sesuatu yang diinginkan selalu dapat diperoleh tanpa melanggar perilaku moral. Relativisme mengacu pada tingkat dimana seorang individu menolak peraturan moral untuk menuntun tingkah laku.

Penelitian akuntansi mengenai pengaruh orientasi etika pada perilaku moral seperti yang dilakukan oleh Shaub et al (1993) yang mengatakan bahwa 
seorang individu yang berorientasi secara ideal akan cenderung fokus pada peraturan dan pedoman moral. Sebaliknya seorang individu yang berorientasi lebih relativistik memberi toleransi peraturan moral yang disepakati bersama dan menganggap masalah etika dapat diinterpretasikan dari perspektif yang berbeda.

Sedangkan faktor -faktor pribadi mahasiswa lain yang diukur dengan locus of control merupakan kekuatan yang dipercaya oleh seorang individu sebagai bentuk tanggung jawab terhadap ganjaran dan hukuman terhadap dirinya (Rotter, 1996). Locus of control dianggap sebagai suatu ciri watak kepribadian yang teguh atau stabil yang terdapat pada diri seorang individu (Lampe dan Finn, 1992). Dan locus of control juga sebagai ciri watak kepribadian yang memberikan pengaruh terhadap pembuatan keputusan dan tingkah laku moral pada diri seseorang tersebut (Chiu, 2001; Chan dan Leung, 2006). Hal ini diharapkan bahwa seseorang yang "internal" akan menerima suatu kejadian dari tingkah laku yang dimiliki oleh seseorang tersebut, sedangkan masalah etika seseorang yang "eksternal" akan menerima suatu kejadian dari kekuatan dari luar atau dari tingkah laku orang lain.

Sifat -sifat pribadi yang sering dinyatakan sebagai variabel-variabel yang mempengaruhi proses pembuatan keputusan (Allen et al., 2001; Hartikainen dan Torstila, 2004) yaitu variabel demografis yang mempengaruhi perilaku moral mahasiswa diantaranya, yaitu: Jenis kelamin (Thoma, 1984; Shaub, 1993; Thorne, 2000; Simga-Maugan et al., 2005; Chan dan Leung. 2006). Indeks Prestasi Kumulatif (Sweeney dan Robert, 1991; Shaub et al., 1993; Chan dan Leung, 2006), dan Umur (Thoma, 1984; Comunale et al., 2006), yang menunjukkan suatu hubungan dengan tingkat pertimbangan moral (Thoma. 1984; Comunale e al., 2006), sensitivitas moral, motivasi moral dan karakter moral ( Chan dan Leung, 2006; 1996; Shaub et al., 1993)

Hipotesis yang dibuat untuk menguji pengaruh - pengaruh faktor - faktor pribadi mahasiswa yang diukur dengan tingkat idealisme dan tingkat relativisme, locus of control dan demografis terhadap perilaku mahasiswa akuntansi secara parsial dalam penelitian ini sebagai berikut.
$\mathrm{H}_{2}$ : Pemikiran moral dan faktor - faktor pribadi mahasiswa berpengaruh signifikan terhadap perilaku moral mahasiswa secara Parsial

Dari hipotesis yang dirumuskan di atas, maka kerangka penelitian dapat digambarkan sebagai berikut:

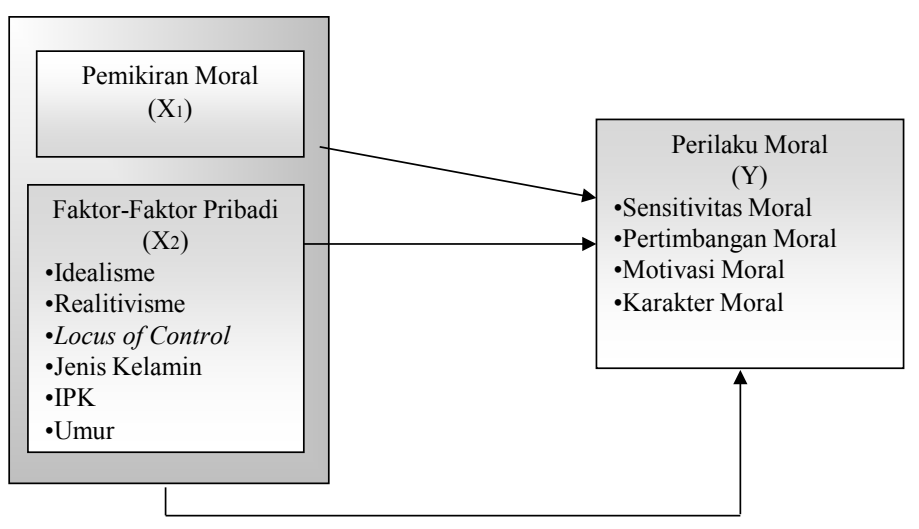

Gambar 1 Kerangka Pemikiran

\section{HASIL DAN PEMBAHASAN}

Responden dalam penelitian ini berjumlah 150 yang terdiri dari 58 mahasiswa laki-laki (38.7\%) dan 92 perempuan (61.3\%). Untuk umur responden sampai 20 tahun sebanyak 66 mahasiswa (44\%), umur 20 tahun sebanyak 62 mahasiswa (41.3\%), dan 22 tahun ke atas sebanyak 22 mahasiswa (14.7\%). Indeks Prestasi Kumulatif (IPK) B sebanyak 80 mahasiswa (53.3\%) dan IPK C sebanyak 70 mahasiswa (46.7\%).

\section{Uji Kualitas Data}

Uji kualitas data meliputi uji reliabilitas dan uji validitas menggunakan SPSS Ver. 19. Uji relibilitas dilakukan dengan uji Cronbach Alpha dengan nilai Cronbach Alpha >0,60 dan uji validitas dengan melihat Correlated item-Total Correlation . $r$ tabel product moment dengan signifikansi 5\%. Hasil uji reliabilitas menggunakan Cronbach's Alpha, semua alat ukur variabel dependen dalam penelitian ini, yang terdiri dari variabel sensitivitas moral, pertimbangan moral, motivasi moral dan karakter moral serta variabel independen yang terdiri dari pemikiran moral, idealisme, dan relativisme mempunyai nilai Cronbach's Alpha lebih besar dari 0,60. Hal tersebut menunjukkan bahwa alat ukur yang dipakai dalam penelitian ini adalah reliabel atau handal. Sedangkan hasil dari uji validitas menunjukan bahwa semua nilai $r$ hitung lebih besar dari nilai $r$ table product moment pada taraf signifikansi 5\% untuk n150 adalah 0.01593 
sehingga dapat disimpulkan bahwa semua item pernyataan yang digunakan sebagai alat ukur dalam penelitian ini adalah valid.

\section{Uji Asumsi Klasik}

Pengujian asumsi klasik yang dilakukan dalam penelitian ini adalah uji normalitas dengan menggunakan analisis grafik (Normal Probability Plot) dan uji kolmogorov semirnov terhadap variabel dependen yang seluruhnya terdistribusi secara normal. Hasil uji multikolonieritas terhadap variable independen nilai tolerance menunjukkan tidak ada variabel independen yang memiliki tolerance kurang dari 0,10 (VIF dibawah 10) yang berarti tidak ada korelasi antar variabel independen yang nilainya lebih dari $95 \%$ atau semua variable independen tidak ada multikolonieritas. Sedangkan dari hasil uji heterokedastisitas dengan uji Park mengindikasikan nilai probabilitas signifikansinya di atas tingkat kepercayaan $5 \%$ atau, nilai signifikansi korelasinya lebih besar dari 0.05 . yang berarti dapat disimpulkan bahwa model regresi yang digunakan tidak mengandung heteroskedastisitas. Hasil uji heterokedasitas dengan menggunakan analisis grafik Scatter plott dapat diketahui bahwa tidak ada pola yang jelas, serta titik-titik menyebar secara acak serta tersebar baik diatas maupun dibawah angka 0 pada sumbu Y, maka dapat disimpulkan bahwa tidak terjadi heterokedastisitas pada model regresi, sehingga model regresi dinyatakan layak untuk digunakan. Mengenai hasil penelitian uji asumsi klasik dapat dilihat tabel $8,9,10,11,12$ dan 13 pada lampiran.

Pengujian dan Pembahasan Hipotesis Pengujian Pemikiran Moral dan Faktor - Faktor Pribadi Mahasiswa Berpengaruh Signifikan Terhadap Perilaku Moral Mahasiswa Secara Simultan

Tabel 1 Uji Statistik F

\begin{tabular}{|c|c|c|c|c|c|c|}
\hline \multicolumn{7}{|c|}{ ANOVA $^{b}$} \\
\hline & Model & Sum of Squares & df & $\begin{array}{l}\text { Mean } \\
\text { Square }\end{array}$ & $\mathbf{F}$ & Sig. \\
\hline \multirow[t]{3}{*}{1} & Regression & 8571.768 & 6 & 1428.628 & 39.807 & .000 \\
\hline & Residual & 5132.105 & 143 & 35.889 & & \\
\hline & Total & 13703.873 & 149 & & & \\
\hline
\end{tabular}

Hipotesis pertama disebutkan bahwa pemikiran moral dan faktor-faktor pribadi mahasiswa berpengaruh positif dan signifikan terhadap perilaku moral mahasiswa akuntansi Fakultas Ekonomi Universitas Pancasila secara simultan. Meskipun faktor - faktor pribadi mahasiswa yang diukur dengan locus of control, jenis kelamin, indeks prestasi kumulatif, dan umur secara analisis statistik masing-masing tidak memiliki pengaruh yang signifikan terhadap perilaku moral, namun keenam variabel yang ada, secara bersama-sama dapat mempengaruhi perilaku moral secara signifikan. Hal ini disebabkan karena mahasiswa yang memilki kemampuan berpikir secara moral dan mempunyai tingkat idealisme yang tinggi akan lebih mampu untuk mengetahui hadirnya masalah-masalah etika serta mampu untuk membuat suatu keputusan moral dengan melihat kebenaran pasti dari tindakan moral yang seharusnya dilakukan. Dengan pemikiran moral dan tingkat idealisme yang tinggi, mahasiswa akuntansi akan menemukan adanya masalah etika dan dalam memutuskan suatu tindakan lebih mengarah pada pedoman atau aturan yang telah ditetapkan sebelumya. Begitu pula dengan mahasiswa yang memiliki tingkat relativisme tinggi akan lebih memberikan toleransi dalam menemukan masalah moral serta menimbulkan ego dan karakter dalam melaksanakan pedoman, tindakan atau aturan dalam menyelesaikan masalah moral yang berlaku.

Meskipun faktor-faktor pribadi mahasiswa seperti locus of control, jenis kelamin, indeks prestasi kumulatif dan umur tidak mempunyai pengaruh yang signifikan dan hanya merupakan variabel pengendali namun ke enam variabel faktor-faktor pribadi ini secara bersama-sama dapat mempengaruhi perilaku moral mahasiswa secara signifikan dikarenakan locus of control telah dianggap suatu dari ciri watak kepribadian yang lebih teguh atau stabil yang ada pada diri individu mahasiwa. Hal ini membuktikan bahwa mahasiswa akuntansi Fakultas Ekonomi Universitas Pancasila yang dikarakterkan sebagai internal adalah lebih menunjukkan kemampuan untuk menemukan masalah - masalah moral yaitu mahasiswa akuntansi Fakultas Ekonomi Universitas Pancasila tersebut mempunyai kepercayaan bahwa apa yang dihasilkan merupakan hasil dari usahanya sendiri daripada mahasiswa - mahasiswa lain yang dikarakterkan sebagai eksternal yaitu mahasiswa akuntansi Fakultas Ekonomi Universitas Pancasila beranggapan bahwa 
hasil yang diperoleh dikarenakan soal - soal tersebut mudah dan lebih dipengaruhi oleh faktor - faktor luar dari mahasiswa. Sedangkan pengaruh jenis kelamin muncul ketika perbedaan antara laki-laki dan wanita terjadi dalam pengambilan keputusan moral yaitu para wanita menpunyai tingkat perkembangan moral yang lebih tinggi secara signifikan daripada para lakilaki. begitu juga dengan indeks prestasi kumulatif mahasiswa merupakan nilai dari mata kuliah yang ditempuh oleh mahasiswa akuntansi sebagai bahan pengambilan keputusan diantara para mahasiwa yang berpengetahuan mengenai perkembangan dan profesi akuntansi. Penggunaan faktor umur dapat memberikan suatu dampak terhadap sejauh mana umur memberikan pengaruh terhadap perilaku moral mahasiswa. Mahasiswa yang lebih muda cenderung lebih sedikit fokus terhadap masalah-masalah etika daripada mahasiswa yang lebih tua.

Pengujian Pemikiran Moral dan Faktor - Faktor Pribadi Mahasiswa Berpengaruh Signifikan Terhadap Perilaku Moral Mahasiswa Secara Parsial

Hasil regresi berganda yang dilakukan untuk menguji hipotesis ditampilkan dalam tabel 2 .

Tabel 2 Uji Statistik t

\begin{tabular}{|c|c|c|c|c|c|c|}
\hline \multicolumn{7}{|c|}{ Coefficient $^{a}$} \\
\hline & \multirow[b]{3}{*}{ Model } & \multicolumn{2}{|c|}{$\begin{array}{c}\text { Unstandardized } \\
\text { Coefficient }\end{array}$} & \multirow{3}{*}{$\begin{array}{c}\begin{array}{c}\text { Unstandardized } \\
\text { Coefficient }\end{array} \\
\text { Beta }\end{array}$} & \multirow[b]{3}{*}{$\mathbf{t}$} & \multirow[b]{3}{*}{ Sig. } \\
\hline & & B & Std. & & & \\
\hline & & & Error & & & \\
\hline \multirow[t]{7}{*}{1} & (Constant) & -18.963 & 18.459 & & -1.027 & .306 \\
\hline & Pemikiran moral & .732 & .053 & .757 & 13.930 & .000 \\
\hline & Idealisme Relativisme & .072 & .063 & .061 & 1.142 & .004 \\
\hline & DLOC & -.102 & .213 & -.025 & -.481 & .631 \\
\hline & DJK & .627 & 1.035 & .032 & .606 & .545 \\
\hline & DIPK & 1.266 & 1.018 & .066 & 1.244 & .216 \\
\hline & DU & 1.206 & .732 & .089 & 1.649 & .101 \\
\hline
\end{tabular}

Dependent Variable: Prilakumoral

Hasil analisis hipotesis membuktikan bahwa pemikiran moral mahasiswa akuntansi Fakultas Ekonomi Universitas Pancasila berpengaruh positif dan signifikan terhadap perilaku moral mahasiswa akuntansi. Hal ini membuktikan bahwa pemikiran moral mahasiswa akuntansi Fakultas Ekonomi Universitas Pancasila berdasarkan penelitian ini secara garis besarnya sudah bertingkah laku secara moral berdasarkan empat proses psikologi dasar untuk berperilaku secara moral. Berdasarkan penelitian ini mahasiswa akuntansi Fakultas Ekonomi Universitas Pancasila dengan pemikiran moral yang tinggi mampu untuk menentukan benar atau salah secara moral, mampu membuat keputusan moral terhadap kebenaran yang pasti dari tindakan secara moral, mampu memprioritas nilai moral yang relatif berhubungan dengan nilai moral lainnya serta mampu mengatasi rintangan yang dialami dengan kekuatan dan ego yang dimiliki mahasiswa akuntansi Fakultas Ekonomi Universitas Pancasila. Sehingga mahasiwa akuntansi Fakultas Ekonomi Universitas Pancasila akan lebih sensitif, lebih memiliki kemampuan pertimbangan moral, lebih memiliki kemampuan untuk mempriortitaskan nilai moral dan memilki kemampuan untuk mengatasi rintangan-rintangan untuk menilai suatu kejadian sebagai tindakan moral dalam konteks skenario etika profesional.

\section{Pengujian Faktor - Faktor Pribadi Mahasiswa Berpengaruh Signifikan Terhadap Perilaku Moral Mahasiswa Secara Parsial \\ Hasil regresi berganda yang dilakukan untuk menguji hipotesis ditampilkan dalam tabel 2 .}

Hasil analisis hipotesis membuktikan bahwa faktor-faktor pribadi mahasiswa yang di ukur dengan tingkat idealisme dan tingkat relativisme berpengaruh positif dan signifikan terhadap perilaku moral mahasiswa. Hal ini membuktikan bahwa tingkat idealisme dan tingkat relativisme mahasiswa akuntansi Fakultas Ekonomi Universitas Pancasila menunjukkan pengaruh signifikan terhadap kemampuan mahasiswa dalam mengakui adanya persoalan-persoalan moral, kemampuan mahasiswa dalam pertimbangan membuat keputusan moral, kemampuan mahasiswa dalam membangun motivasi moral untuk memprioritaskan nilai moral yang relatif berhubungan dengan nilai lainnya dan kemampuan mahasiwa dalam mewujudkan karakter moral untuk mengatasi rintangan-rintangan atau permasalahan dalam konteks skenario etika profesional. Mahasiswa akuntansi yang diorientasikan lebih idealis, akan lebih sensitif, akan lebih melakukan pertimbangan yang matang dalam pengambilan keputusan, akan lebih memprioritaskan nilai moral yang relatif berhubungan dengan nilai lainnya dan akan lebih mampu untuk mengatasi rintangan-rintangan dalam persoalanpersoalan etika profesi. Sedangkan mahasiswa 
akuntansi Fakultas Ekonomi Universitas Pancasila yang memiliki tingkat relativisme tinggi mempunyai pengaruh signifikan terhadap kemampuan mahasiswa dalam mentolerir dan memberikan pertimbangan moral adanya persoalan-persoalan moral dalam konteks skenario etika profesional.

Sedangkan faktor - faktor pribadi mahasiswa yang di ukur dengan locus of control, jenis kelamin, indeks prestasi kumulatif, dan umur berpengaruh tidak signifikan terhadap perilaku moral mahasiswa. Hal ini membuktikan bahwa faktor-faktor pribadi mahasiswa akuntansi Fakultas Ekonomi Universitas Pancasila tidak terdapat pengaruh terhadap perilaku moral mahasiswa akuntansi dalam membuat keputusan moral dalam konteks skenario etika profesional.

\section{SIMPULAN}

Pemikiran moral dan faktor-faktor pribadi mahasiswa berpengaruh positif dan signifikan terhadap perilaku moral mahasiswa akuntansi Fakultas Ekonomi Universitas Pancasila secara simultan. Meskipun faktor - faktor pribadi mahasiswa yang di ukur dengan locus of control, jenis kelamin, indeks prestasi kumulatif, dan umur secara analisis statistik masing-masing tidak memiliki pengaruh yang signifikan terhadap perilaku moral, namun keenam variabel yang ada, secara bersama-sama dapat mempengaruhi perilaku moral secara signifikan.

Pemikiran moral dan faktor - faktor pribadi mahasiswa yang diukur dengan tingkat idealisme dan tingkat relativisme berpengaruh positif dan signifikan terhadap perilaku moral mahasiswa akuntansi Fakultas Ekonomi Universitas Pancasila Hal ini membuktikan bahwa pemikiran moral dan faktorfaktor pribadi mahasiswa akuntansi Fakultas Ekonomi Universitas Pancasila berdasarkan penelitian ini secara garis besarnya sudah bertingkah laku secara moral berdasarkan empat proses psikologi dasar untuk berperilaku secara moral dalam mengakui adanya persoalan-persoalan moral, kemampuan mahasiswa dalam pertimbangan membuat keputusan moral, kemampuan mahasiswa dalam membangun motivasi moral untuk memprioritaskan nilai moral yang relatif berhubungan dengan nilai lainnya dan kemampuan mahasiwa dalam mewujudkan karakter moral untuk mengatasi rintangan-rintangan atau permasalahan serta mampu mentolerir dan memberi pertimbangan moral adanya persoalan - persoalan moral dalam konteks skenario etika profesional.

Sedangkan faktor - faktor pribadi mahasiswa yang di ukur dengan locus of control, jenis kelamin, indeks prestasi kumulatif, dan umur berpengaruh tidak signifikan terhadap perilaku moral mahasiswa. Hal ini membuktikan bahwa faktor-faktor pribadi mahasiswa akuntansi Fakultas Ekonomi Universitas Pancasila tidak terdapat pengaruh terhadap perilaku moral mahasiswa akuntansi dalam membuat keputusan moral dalam konteks skenario etika profesional.

\section{DAFTAR PUSTAKA}

Allen, P. W., \& Ng, C. K. (2001). Self interest among CPAs may influence their moral reasoning. Journal of Business Ethics. Vol. 33 No. 1, pp. 29-35.

Andri, N. (2008). Intensitas Moral Mahasiswa Akuntansi: Gambaran Calon Akuntan Profesional, Jurnal Fokus Ekonomi, Vol.03, No.01, pp.35-47.

Arifin, S. (2005). Peran Akuntan dalam Menegakkan Prinsip Good Corporate Governance (Tinjauan Perspektif Agency Theory). Semarang: Badan Penerbit Universitas Diponegoro.

Barnett, T., Bass, K., \& Brown, G. (1994). Ethical Ideology and Ethical Judgment Regarding Ethical Issues in Business. Journal of Business Ethics. 13:469-480.

Bebeau, M. J., Rest, J. R., \& Yamoor C. M. (1985). Measuring Dental Students' Ethical Sensitivity. Journal of Dental Education. Vol. 49. pp. 225-235.

Blackburn, R. (2002). The Enron Debacle and The Pension Crisis. New Left Review. 14: 26-51.

Brownell, \& Peter. (1982). A Field Study Examination of Budgetary Participation and Locus of Control. The Accounting Review, October, 766-777. 
Buchan, H. F. (2005). Ethical Decision Making in the Public Accounting Profession: an Extension of Ajzen's Theory of Planned Behavior. Journal of Business Ethics, Vol. 61 No. 2, pp. 165-81.

Chan, Samuel, Y. S., Leung, \& Philomena. (2006). The Effect of Accounting Student's Ethical Reasoning and Personel Factors on Their Ethical Sensitivity. Managerial Auditing Journal, Vol. 21, No. 4, pp. 436-457.

Cohen, J. R., \& Bennie, N. M. (2006). The Applicability of a Contingent Factors Model to Accounting Ethics Research. Journal of Business Ethics, Vol. 68, pp. 1-18.

Cohen, J. R., Pant, L. W. \& Sharp, D. J. (2001). An Examination of Differences in Ethical Decision-making Between Canadian Business Students and Accounting Professional. Journal of Business Ethics. Vol. 30 No. 4, pp.319-36.

Comunale, C. L., Sexton, T. R., \& Gara, S. C. (2006). Profesional Ethical Crises: a Case Study of Accounting Majors. Managerial Auditing Journal, Vol. 21, No. 6, pp. 636-656

Ellias, R. Z. (2002). Determinants of Earnings Management Ethics among Accountants. Journal of Business Ethics, Vol. 40 No. 1, pp. 33-45.

Falah, S. (2006). Pengaruh Budaya Etis Organisasi dan Orientasi Etis terhadap Sensitivitas Etis, Tesis Magister Sains Akuntansi, Universitas Diponegoro, Semarang .Tidak Dipublikasikan.

Febrianty. (2011). Perkembangan Model Moral Kognitif dan Relevansinya dalam Riset-Riset Akuntansi, Jurnal Ekonomi Dan Informasi Akuntansi (Jenius), Vol.01, No.01, pp.57-77.

Forsyth, D. R. (1980). A Taxonomy of Ethical Ideologies. Journal of Personality and Social Psychology, Vol. 39, pp. 175-84.
Fraedrich, J. P., \& Ferrell, O. C. (1992a). Cognitive Consistency of Marketing Managers in Ethical Situations. Journal of Academy of Marketing Science, 20, 245-252.

Ghozali, \& Imam. (2005), Analisis Multivariate dengan Program SPSS. Semarang: Badan Penerbit Universitas Diponegoro

Gilligan, C. (1982). In a Different Voice Boston, MA: Havard University Press.

Harahap, S. S. (2008). Pentingnya Unsur Etika dalam Profesi Akuntan dan Bagaimana di Indonesia. Ekonomi Islam, (online), (http:// ekisonline.com, diakses 16 maret 2011).

Haris, J. R., \& Sutton, C. D. (1995). Unravelling the Ethical Decision-Making Process: Clues from an empirical study comparing fortune 1000 executives and MBA student., Journal of Business Ethics, 14, 805-817.

Huffman, K. (1991). Psychology in Action. New York: John Wiley and Sons.

Indriantoro, N., \& Supomo, B. (1999). Metodologi Penelitian Bisnis. Yogyakarta: Edisi Pertama. BPFE.

Jeffrey, C., \& Weatherholt, N. (1996). Ethical Development, Professional Commitment, and Rule Observance Attitudes: A Study Case of CPAs and Corporate Accountants. Behavioral Research in Accounting. Vol. 8;831.

Jeffrey, C. (1993). Ethical Development of Accounting Students, Non-accounting Business Students, and Liberal Arts Students. Issues in Accounting Education. Vol. 8 No. 1, pp. 86-96.

Kamus Besar Bahasa Indonesia (1998). Departemen Pendidikan dan Kebudayaan, Balai Pustaka.

Karcher, J. N. (1996). Auditors' Ability to Discern the Presence of Ethical Problems. Journal of Business Ethics. Vol. 15 No. 10, pp. 1033-50. 
Keraf, \&Sonny. 2011. Etika Bisnis. Yogyakarta: Penerbit Kanisius.

Kohlberg, L. 1971. Stages of Moral Development as a Basis of Moral Education. DIm. Beck, C.M., Crittenden, B.S. \& Sullivan, E.V.(pnyt.). Moral education: interdisciplinary approaches: 23 92. New York: Newman Press.

Kohlberg, L. (1977). The Cognitive-developmental Approach to Moral Education. DIm. Rogrs, D. Issues in adolescent psychology: 283299. New Jersey: Printice Hall, Inc.

Lampe, J. C., \& Finn, D. W. (1992). A Model of Auditors' Ethical Decision Process. Auditing: A Journal of Practice \& Theory, Supplement, pp. 1-21.

Leung, P., \& Cooper, B. J. (1995). Ethical Dilemmas in Accountancy Practice. Australian Accountant. May, pp. 28-32.

Lovell, A. (1997). Some Thoughts on Kohlberg's Hierarchy of Moral Reasoning and Its Relevance for Accounting Theories of Control. Accounting Education 6

Ludigdo, U., \& Machfoedz, M. (1999). Persepsi Akuntan dan Mahasiswa terhadap Etika Bisnis. Jurnal Riset Akuntansi Indonesia. Vol. 2, no. 1. Januari. Pp. 1-19.

Marwanto. (2007). Pengaruh Pemikiran Moral, Tingkat Idealisme, Tingkat Relativisme, dan Locus of Control terhadap Sensitivitas, Pertimbangan, Motivasi dan Karakter Mahasiswa Akuntansi. Tesis Program Pascasarjana Universitas Diponegoro. Tidak dipublikasikan.

Mele, D. (2005). Ethical Education in Accounting: Integrating Rules, Values and Virtue. Journal of Business Ethics, Vol. 57 No. 1, pp. 97-109

Najmudin, \& Wiwiek, R. A. (2011). Studi Tentang Intervensi Etika Dan Peningkatan Moral, Jurnal Bisnis dan Ekonomi (JBE), Vol.18, No.1, pp.69-83.
Neisser, U. (1976). Cognitive Psychology. New York: Appleton-Cntury-Crofts.

Noor, H. U. (2005). Analisis Perbedaan Faktor-Faktor Individual Terhadap Persepsi Prilaku Etis Mahasiswa, Jurnal Akuntansi \& Auditing, Vol.01, No.02, pp.162-180.

Ponemon, L., \& Glazer, A. (1990). Accounting Education and Ethical Development: the Influence of Liberal Learning on Students and Alumni in Accounting Practice. Issues in Accounting Education, Vol. 6 No. 2, pp. 195208.

Ponemon, L. A., \& Gabhart, D. R. L. (1993). Ethical Reasoning in Accounting and Auditing, Research Monograph Number 21, CGACanada: Research Foundation.

Reidenbach, R. E., \& Robin, D. P. (1990). Toward the Development of a Multidemensional Scales for Improving Evaluations of Business Ethics. Journal of Business Ethics, 9, 639-653.

Rest, J. R. (1979). Revised Manual for The Defining Issues Test. USA: Mineapolis Minnesota Moral Research Projects.

Rest, J.R., (1986). Moral Development: Advances in Research and Theory. New York, NY: Praegar.

Robbins, S. P. (2003). Perilaku Organisasi. Jakarta: PT. Indeks.

Rotter, J. B. (1966.) Generalized Expectancies for Internal Versus External Control of Reinforcement. Psychological Monograph, General and Applied, Vol. 80 No. 1, (Whole No. 609).

Sankaran, S., \& Bui, T. (2003). Ethical Attitudes Among Accounting Majors: an empirical study. Journal of the American Academy of Business, Vol. 3, Nos. 1/2, pp. 71-77.

Santoso, \& Kanto. (2002).

Enron terhadap

D a $m$ p a k

Citra Profesi Kebangkrutan Akuntan Publik, 
Jakarta:.Media Akuntansi, Edisi 25/April/ Tahun IX/2002.

Schlenker, B. R., \& Forsyth, D. R. (1977). On the Ethics of Psychological Research. Journal of Experimental Social Psychology, Vol. 13, pp. 369-96.

Shaub, M. (1989). An Empirical Examination of the Determinants of Auditor Ethical Sensitivity. Unpublished Ph.D. desertation, Texas Tech University.

Shaub, M., Finn, D. W., \& Munter, P. (1993). The effects of auditors' ethical orientation on commitment and ethical sensitivity. Behavioural Research in Accounting, Vol. 5, pp. 145-69.

Shoemaker, D. W. (2000). Reductionist Contractualism: Moral Motivation and Expanding Self. Canadian Journal of Philosophy. Vol. 30, No. 3, pp. 343-370.

Siti, M. (2006). Studi Tentang Perbedaan Evaluasi Etis, Intensitas Etis (Ethical Intention) Dan Orientasi Etis Dilihat Dari Gender Dan Disiplin IImu: Pontensi Rekruitment Staf Profesional Pada Kantor Akuntan Publik Simposium Nasional Akuntansi 9 Padang, 23-26 Agustus.

Sugandhi, R. (1980). Kitab Undang-Unda Hukum Pidana dan Penjelasannya, Usaha Nasional, Surabaya.

Suparno, P. (2010). Teori Perkembangan Kognitif Jean Piaget. Yogyakarta: Penerbit Kanisius.
Sweeney, J. (1995). The Moral Expertise of Auditors: an Exploratory Analysis. Research on Accounting Ethics. Vol. 1, pp. 213-34.

Sweeney, J., \& Roberts, R. (1997). Cognitive Moral Development and Auditor Independence. Accounting, Organization and Society, 22, 337-352.

Thoma, S. (1986). Estimating Gender Differences in the Comprehension and Preference of Moral Issues,.Development Review, 6: 165180.

Thorne, L. (2000). The Development of ContextSpecific Measures of Accountants' Ethical Reasoning. Behavioral Research in Accounting 12,139-170.

Tsui, J. (1994). Auditors' Ethical Behaviour; a Study of the Determinants of Auditors' Decision Making in an Audit Conflict Situation, Unpublished Doctoral Dissertation. Hong Kong: The Chinese University of Hong Kong.

Volker, J. M. (1984). Counseling Experience, Moral Judgment, Awareness of Consequences, and Moral Sensitivity in Counseling Practice, Unpublished Doctoral Dissertation. Minneapolis, MN: University of Minnesota Press.

Walker, L. J. (2002). The Character of Moral Exemplars. Columbia: University of British.

Zajonc, R. B., Murphy S. T., \& Inglehart. (1989). Feeling Efference. Implication of the Vascular Theory of Emotion. Psychological Review, Vol 96, No 3. 